\title{
Crystal Structure of Bis(diphenylphosphino)ethane Bis(2-selenopyridinato)platinum(II)
}

\author{
Neratur K. LoKanath,* Hirihalli C. DevaraJEgowda, * Sridhar M. Anandalwar, *† \\ Javaregowda Shashidhara PraSAd, * Sanjay NARAYAN,** and Vimal K. JAIN**
}

*Department of Studies in Physics, University of Mysore, Manasagangotri, Mysore 570 006, India

**Novel Materials and Structural Chemistry Division, Bhabha Atomic Research Centre,

Mumbai 400 085, India

(Received April 10, 2000; Accepted December 1, 2000)

The chemistry of platinum-group organochalcogenolates has attracted considerable attention in recent years due to their diverse structural possibilities and relevance in materials science. ${ }^{1-3}$ Mononuclear cis complexes, $\left[\mathrm{M}(\mathrm{ER})_{2} \mathrm{~L}_{2}\right]$, are useful precursors for the synthesis of bi- and poly-nuclear

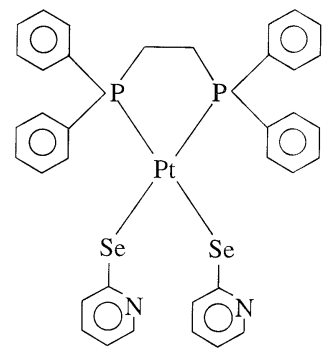

Fig. 1 Schematic diagram of $\left[\operatorname{Pt}(\text { Sepy })_{2}(\right.$ dppe $\left.)\right]$.

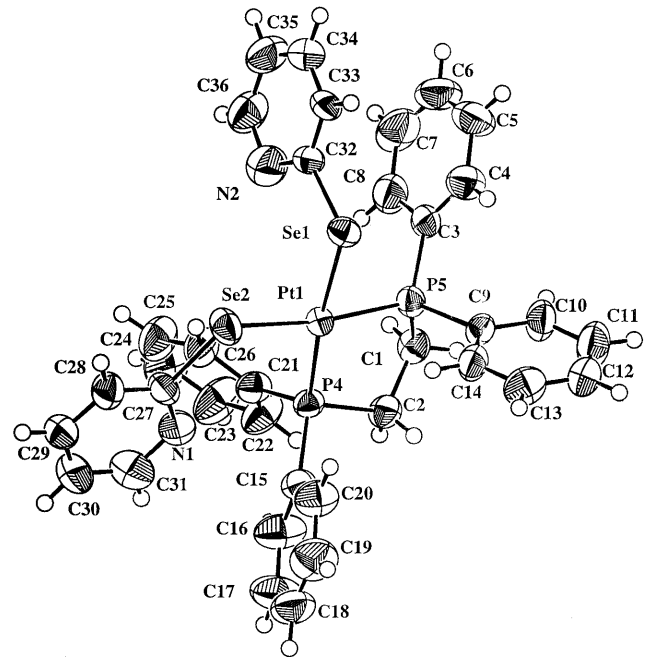

Fig. 2 ORTEP with numbering scheme of $\left[\mathrm{Pt}(\mathrm{Sepy})_{2}(\mathrm{dppe})\right]$ at $50 \%$ probability.

$\uparrow$ To whom correspondence should be addressed.

E-mail:mas@uomphysics.net complexes. ${ }^{2,3}$ These complexes are usually derived from simple organochalcogenolate ions. Internally functionalized organochalcogenolates, such as 2-selenopyridinate, would provide additional donor sites and, consequently, may result in a new structural motif. ${ }^{5}$ The structure of one such complex $\left[\mathrm{Pt}(\text { Sepy })_{2}(\mathrm{dppe})\right]$ is reported herein

A schematic diagram of $\left[\mathrm{Pt}(\mathrm{Sepy})_{2}(\mathrm{dppe})\right]$ is shown in Fig. 1. Thermal ellipsoids of $\left[\mathrm{Pt}(\mathrm{Sepy})_{2}(\mathrm{dppe})\right]$ are shown in Fig. 2. Crystal and experimental data are listed in Table 1. The fractional atomic coordinates and equivalent thermal paprameters for all of the refined atoms are given in Table 2. The platinum atom exists in a square-planar geometry defined by two cis selenium atoms derived from the 2-selenopyridinate ion and two phosphorus atoms of the chelating dppe ligand. Heavier atoms are all in a plane, whereas two carbon atoms of the dppe ligand are out of plane by the same extent on either side $( \pm 0.37 \AA)$. The Pt-Se distances of $2.4335(13) \AA$ and $2.4980(14) \AA$ are clearly not equivalent. The distances can be compared with the $\mathrm{M}-\mathrm{Se}$ distances reported for $\left[\mathrm{Pt}(\mathrm{SePh})_{2}(\mathrm{dppe})\right]^{2}$ and $\left[\mathrm{Pd}(\mathrm{SePh})_{2}(\mathrm{dppe})\right]^{3} \quad$ The $\mathrm{Pt}-\mathrm{P}^{2}, \mathrm{Pt}^{3} \mathrm{Se}^{2}$ and $\mathrm{P}-\mathrm{C}^{2,3}$ are in good agreement with those reported earlier. The P-Pt-P $\left(85.3(9)^{\circ}\right)$ and Se-Pt-Se $\left(81.52(5)^{\circ}\right)$ angles are significantly reduced from the normal bond angles of $90^{\circ}$. The latter angle is usually acute; the E-M-E angles $(\mathrm{E}=\mathrm{S}$ or $\mathrm{Se} ; \mathrm{M}$

Table 1 Crystal and structure refinement data 
Table 2 Atomic coordinates and equivalent isotropic displacement parameters $\left(\AA^{2}\right)$

\begin{tabular}{|c|c|c|c|c|}
\hline Atom & $x$ & $y$ & $z$ & $U_{\mathrm{eq}}$ \\
\hline Pt1 & $0.141964(11)$ & $0.19948(4)$ & $0.330946(17)$ & $0.0403(2)$ \\
\hline Se1 & $0.14408(3)$ & $0.42305(12)$ & $0.26967(5)$ & $0.0481(3)$ \\
\hline $\mathrm{Se} 2$ & $0.13397(5)$ & $0.39429(13)$ & $0.39481(6)$ & $0.0605(4)$ \\
\hline $\mathrm{P} 4$ & $0.14284(7)$ & $-0.0187(3)$ & $0.38085(11)$ & $0.0435(5)$ \\
\hline P5 & $0.14920(7)$ & $0.0548(3)$ & $0.26078(11)$ & $0.0445(5)$ \\
\hline N1 & $0.1277(4)$ & $0.1792(11)$ & $0.4750(6)$ & $0.067(3)$ \\
\hline N2 & $0.0522(4)$ & $0.3795(16)$ & $0.1989(7)$ & $0.087(3)$ \\
\hline $\mathrm{C} 1$ & $0.1394(3)$ & $-0.1380(11)$ & $0.2710(5)$ & $0.052(2)$ \\
\hline $\mathrm{C} 2$ & $0.1596(4)$ & $-0.1647(11)$ & $0.3458(5)$ & $0.053(2)$ \\
\hline C3 & $0.1146(3)$ & $0.0936(12)$ & $0.1736(5)$ & $0.052(2)$ \\
\hline $\mathrm{C} 4$ & $0.1287(5)$ & $0.1759(15)$ & $0.1389(6)$ & $0.069(3)$ \\
\hline C5 & $0.0996(6)$ & $0.2099(15)$ & $0.0711(7)$ & $0.082(4)$ \\
\hline C6 & $0.0572(6)$ & $0.172(2)$ & $0.0409(7)$ & $0.093(5)$ \\
\hline $\mathrm{C} 7$ & $0.0432(5)$ & $0.097(2)$ & $0.0746(8)$ & $0.096(5)$ \\
\hline C8 & $0.0713(4)$ & $0.0600(17)$ & $0.1412(6)$ & $0.073(3)$ \\
\hline C9 & $0.2034(3)$ & $0.0509(10)$ & $0.2794(5)$ & $0.047(2)$ \\
\hline $\mathrm{C} 10$ & $0.2135(4)$ & $-0.0319(16)$ & $0.2407(6)$ & $0.067(3)$ \\
\hline C11 & $0.2557(4)$ & $-0.0405(18)$ & $0.2577(8)$ & $0.085(4)$ \\
\hline $\mathrm{C} 12$ & $0.2864(4)$ & $0.0366(17)$ & $0.3120(7)$ & $0.074(3)$ \\
\hline C13 & $0.2770(4)$ & $0.1194(16)$ & $0.3508(7)$ & $0.074(3)$ \\
\hline $\mathrm{C} 14$ & $0.2347(4)$ & $0.1216(17)$ & $0.3336(6)$ & $0.069(3)$ \\
\hline $\mathrm{C} 15$ & $0.1817(3)$ & $-0.0510(12)$ & $0.4695(5)$ & $0.053(2)$ \\
\hline $\mathrm{C} 16$ & $0.1778(5)$ & $-0.1671(17)$ & $0.5029(8)$ & $0.086(5)$ \\
\hline C17 & $0.2088(7)$ & $-0.197(2)$ & $0.5685(9)$ & $0.106(6)$ \\
\hline C18 & $0.2449(5)$ & $-0.1067(19)$ & $0.6009(7)$ & $0.086(4)$ \\
\hline C19 & $0.2487(5)$ & $0.004(2)$ & $0.5651(8)$ & $0.096(5)$ \\
\hline $\mathrm{C} 20$ & $0.2182(4)$ & $0.0367(15)$ & $0.5008(7)$ & $0.072(3)$ \\
\hline $\mathrm{C} 21$ & $0.0909(3)$ & $-0.0788(12)$ & $0.3600(5)$ & $0.053(2)$ \\
\hline $\mathrm{C} 22$ & $0.0813(4)$ & $-0.2301(15)$ & $0.3575(8)$ & $0.075(4)$ \\
\hline $\mathrm{C} 23$ & $0.0404(5)$ & $-0.271(2)$ & $0.3420(10)$ & $0.094(5)$ \\
\hline $\mathrm{C} 24$ & $0.0117(4)$ & $-0.1687(19)$ & $0.3320(9)$ & $0.091(5)$ \\
\hline $\mathrm{C} 25$ & $0.0213(4)$ & $-0.0189(17)$ & $0.3344(8)$ & $0.082(4)$ \\
\hline $\mathrm{C} 26$ & $0.0598(3)$ & $0.0305(14)$ & $0.3467(6)$ & $0.063(3)$ \\
\hline $\mathrm{C} 27$ & $0.1256(4)$ & $0.3246(12)$ & $0.4629(5)$ & $0.051(2)$ \\
\hline $\mathrm{C} 28$ & $0.1173(4)$ & $0.4246(13)$ & $0.4966(6)$ & $0.060(3)$ \\
\hline $\mathrm{C} 29$ & $0.1099(4)$ & $0.3822(15)$ & $0.5438(5)$ & $0.064(3)$ \\
\hline C30 & $0.1122(5)$ & $0.230(2)$ & $0.5573(8)$ & $0.085(4)$ \\
\hline C31 & $0.1212(6)$ & $0.135(2)$ & $0.5225(8)$ & $0.091(4)$ \\
\hline C32 & $0.0853(3)$ & $0.4491(12)$ & $0.1991(4)$ & $0.049(2)$ \\
\hline C33 & $0.0794(3)$ & $0.5440(14)$ & $0.1528(5)$ & $0.057(3)$ \\
\hline C34 & $0.0404(5)$ & $0.5620(19)$ & $0.1014(6)$ & $0.082(4)$ \\
\hline C35 & $0.0055(4)$ & $0.4939(19)$ & $0.0946(7)$ & $0.086(4)$ \\
\hline C36 & $0.0119(4)$ & $0.3978(17)$ & $0.1443(8)$ & $0.081(4)$ \\
\hline
\end{tabular}

$U_{\mathrm{eq}}=(1 / 3) \sum_{i} \Sigma_{j} U_{i j} a_{i}^{*} a_{j}^{*}\left(\boldsymbol{a}_{i} \cdot \boldsymbol{a}_{j}\right)$.
$=\mathrm{Pd}$ or $\mathrm{Pt})$ in $\left[\mathrm{Pd}(\mathrm{SePh})_{2}(\mathrm{dppe})\right],{ }^{3}\left[\mathrm{Pd}\left(\mathrm{SC}_{6} \mathrm{~F}_{5}\right)_{2}(\mathrm{dppe})\right],{ }^{3}$ and $\left[\mathrm{Pt}(\mathrm{SePh})_{2}(\mathrm{dppe})\right]^{2}$ are $99.11(4)^{\circ}, 100.84(4)^{\circ}$ and $90.70(3)^{\circ}$, respectively. The individual pyridyl rings are planar and inclined to one another by $85.4(8)^{\circ}$ and are $89.3(6)^{\circ}$ to the platinum coordination plane.

\section{Acknowledgements}

The authors would like to express their thanks to Department of Science and Technology, Government of India for financial assistance under the DST project SP/I2/FOO/93.

\section{References}

1. J. Arnold, Prog. Inorg. Chem., 1995, 43, 353.

2. V. K. Jain, S. Kannan, R. J. Butcher, and J. P. Jainski, J. Chem. Soc. Dalton Trans., 1993, 1509.

3. A. Singhal, V. K. Jain, B. Varghese, and E. R. T. Tieknik, Inorg. Chim. Acta, 1999, 285, 190. 